\title{
KINERJA KEUANGAN PADA HOTEL MILIK XYZ DENGAN PENGGUNAAN OPERATOR HOTEL
}

\section{FINANCIAL PERFORMANCE IN XYZ HOTELS USING HOTEL OPERATORS}

\author{
Miranti $^{* 1}$, Noer Azam Achsani* ${ }^{*}$, dan Bayu Bandono ${ }^{* *}$ \\ *) Sekolah Bisnis, IPB University \\ Jl. Padjajaran, Bogor, Indonesia 16151, Indonesia \\ ${ }^{* *}$ Otoritas Jasa Keuangan
}

Gedung Soemitro Djojohadikusumo, Jl. Lapangan Banteng Timur 2-4, Jakarta 10710, Indonesia

\begin{abstract}
The purpose of this study is to analyze the financial performance of XYZ's hotels by using hotel operators. XYZ's hotels for the last nine years have been managed by AHH to increase the productivity of hotel performance. Historical financial performance show that the three XYZ hotels did not achieve the target over the last five years. Meanwhile, until August 2019 XYZ's hotels showed a decrease in income above 5\% and net profit after tax above $40 \%$. To analyze hotel financial performance used financial ratios, company value added (EVA), and dividend payout ratio. Next to analyze the differences in the financial performance of XYZ hotels between before and after managed by hotel operators used the t-independent test method. The results of the analysis of financial performance show that MHH and SPH had good hotel financial performance during the study period, while $B I H$ showed a declined trend in financial performance with negative EVA. The results of the t-independent test research showed that AHH as a hotel operator failed to improve the hotel's financial performance and did not provide added value to the three hotels owned by $X Y Z$.
\end{abstract}

Keywords: financial performance, economic value added, dividend payout ratio, hotel management, hospitality industry

Abstrak: Tujuan dari penelitian ini adalah menganalisis kinerja keuangan ketiga hotel milik XYZ dengan adanya kebijakan penggunaan operator hotel. Hotel XYZ selama sembilan tahun terakhir dikelola oleh operator hotel AHH dengan tujuan untuk peningkatan produktivitas kinerja. Dilihat dari sisi kinerja keuangan, ketiga hotel XYZ menunjukkan ketidaktercapaian realisasi terhadap target selama lima tahun terakhir, bahkan pada periode sampai dengan Agustus 2019 ketiga hotel XYZ mengalami penurunan pendapatan diatas $5 \%$ dan penurunan laba bersih setelah pajak diatas $40 \%$. Untuk menganalisis kinerja keuangan hotel menggunakan rasio keuangan, nilai tambah perusahaan (EVA), dan dividend payout ratio. Selanjutnya untuk menganalisis perbedaan kinerja keuangan hotel XYZ antara sebelum dan sesudah dikelola oleh operator hotel digunakan metode uji t-independen dengan SPSS. Hasil analisis kinerja keuangan memperlihatkan bahwa MHH dan SPH memiliki kinerja keuangan hotel yang baik selama periode penelitian, sementara BIH menunjukkan tren kinerja keuangan yang memburuk dengan EVA negatif. Hasil penelitian uji beda menunjukkan bahwa AHH sebagai operator hotel gagal untuk meningkatkan kinerja keuangan hotel dan tidak memberikan nilai tambah kepada ketiga hotel milik XYZ.

Kata kunci: kinerja keuangan, nilai tambah perusahaan, dividend payout ratio, operator hotel, industri keramahtamahan

${ }^{1}$ Corresponding author:

Email: sayamiranti@gmail.com 


\section{PENDAHULUAN}

Perhotelan dan pariwisata adalah salah satu sektor ekonomi yang paling menjanjikan untuk pertumbuhan jangka panjang dan memberikan kontribusi terhadap kekuatan ekonomi dan perkembangan sosial dunia (WTTC, 2019). Pada tahun 2018, sebagian besar usaha akomodasi memiliki sistem pengelolaan usaha akomodasi sendiri (independen) yakni sebanyak 26 612 usaha atau $94.27 \%$. Sedangkan sisanya sebanyak 474 usaha atau $1.68 \%$ memiliki sistem pengelolaan usaha akomodasi jaringan internasional dan sebanyak 1144 usaha atau 4.05\% memiliki sistem pengelolaan usaha akomodasi jaringan nasional. Apabila dilihat berdasarkan provinsi, provinsi Bali memiliki jumlah usaha akomodasi terbanyak baik usaha akomodasi dengan sistem pengelolaan international chain, national chain, maupun independen.

Memasuki industri 4.0, bisnis manajemen perhotelan mengalami perubahan dengan berdatangannya Virtual Hotel Operator (VHO). Ancaman pesaing baru terhadap jaringan hotel besar yang sudah lama berdiri adalah accommodation sharing yang memanfaatkan teknologi informasi sebagai platform untuk berinteraksi dengan tamu (Belk 2014, Eckhard dan Bardhi 2015, Salvioni 2016). Menurut Wiastuti dan Susilowardhani (2016), keberadaan VHO tidak menjadi faktor pengganggu pada industri perhotelan dan VHO meningkatkan kualitas produk serta menciptakan lebih banyak nilai tambah melalui harga yang kompetitif, kemudahan akses, kemudahan metode pembayaran, dan menjadi forum terbuka untuk review konsumen atas layanan yang diterima.

Salah satu pemain lokal di industri perhotelan adalah $\mathrm{XYZ}$ yang merupakan anak perusahaan Badan Usaha Milik Negara (BUMN) bergerak di industri hospitality dan memiliki tiga anak perusahaan perhotelan yaitu MHH, SPH, BIH serta satu anak perusahaan jasa manajemen hotel yaitu AHH.

Pada tahun 2010, XYZ melakukan sinergi dengan mengalihkan hak pengelolaan ketiga hotelnya kepada AHH sebagai operator hotel mulai tahun 2010. Hal yang menjadi prioritas sebagai perusahaan induk adalah membangun sinergi antar perusahaan yang tergabung dalam kelompok perusahaan serta memberikan dukungan demi terciptanya efisiensi (Susanto 2013). XYZ melakukan evaluasi kinerja keuangan dilakukan secara periodik dan terhadap ketiga hotel XYZ yang dikelola AHH tercatat bahwa realisasi kinerja keuangan tidak mencapai target selama lima tahun terakhir yang dapat dilihat pada Tabel 1.

Tabel 1. Persentase pencapaian kinerja keuangan hotel XYZ tahun 2014-2018

\begin{tabular}{lcccc}
\hline Indikator & & $\mathrm{MHH}$ & $\mathrm{SPH}$ & $\mathrm{BIH}$ \\
\hline Pendapatan & 2014 & $108.3 \%$ & $135.0 \%$ & $82.4 \%$ \\
& 2015 & $93.6 \%$ & $91.6 \%$ & $80.1 \%$ \\
& 2016 & $94.9 \%$ & $117.3 \%$ & $76.8 \%$ \\
& 2017 & $97.2 \%$ & $101.4 \%$ & $95.6 \%$ \\
& 2018 & $91.2 \%$ & $69.1 \%$ & $82.7 \%$ \\
Laba Bersih & 2014 & $98.5 \%$ & $269.0 \%$ & $-137.7 \%$ \\
Setelah Pajak & 2015 & $97.5 \%$ & $103.2 \%$ & $-121.4 \%$ \\
& 2016 & $77.2 \%$ & $177.3 \%$ & $18.1 \%$ \\
& 2017 & $64.3 \%$ & $49.8 \%$ & $-267.8 \%$ \\
& 2018 & $65.5 \%$ & $21.8 \%$ & $-107.7 \%$ \\
\hline
\end{tabular}

Kinerja keuangan sampai dengan Agustus 2019 juga memperlihatkan adanya penurunan pendapatan dan laba bersih setelah pajak. Dilihat dari sisi pendapatan, ketiga hotel tersebut menurun di atas $5 \%$ dan dari sisi laba bersih setelah pajak, ketiga hotel tersebut menurun di atas $40 \%$. Dibandingkan dengan pesaing yang bergerak di industri perhotelan lainnya, pada periode sampai dengan Agustus 2019, ketiga hotel XYZ memiliki kinerja keuangan dari sisi pendapatan dan laba bersih setelah pajak yang menurun, sementara pesaing menunjukkan pertumbuhan pendapatan sebesar $17.0 \%$ dan laba bersih setelah pajak sebesar 485.0\% sebagaimana terlihat pada Gambar 1. Hal tersebut menunjukkan bahwa ketiga hotel XYZ tidak memberikan kinerja yang selaras dengan tren industri.

Pada umumnya, antara pemilik hotel dan pengelola hotel ditetapkan suatu kontrak atau perjanjian manajemen hotel yang dirancang khusus oleh kedua belah pihak dan bukan merupakan suatu kontrak standar. Dalam kerjasama pengelolaan hotel, beberapa pemilik hotel memutuskan kontrak manajemen dengan alasan target penghasilan yang disepakati tidak tercapai dan biaya untuk pengelola terlalu besar (Juliana dan Pramono 2003). AHH dan hotel XYZ memiliki perjanjian pengelolaan hotel sejak tanggal 01 Januari 2010. Kondisi ketidaktercapaian pendapatan dan laba yang dihasilkan setelah dikelola AHH dapat mengakibatkan pemutusan perjanjian pengelolaan hotel oleh XYZ. 


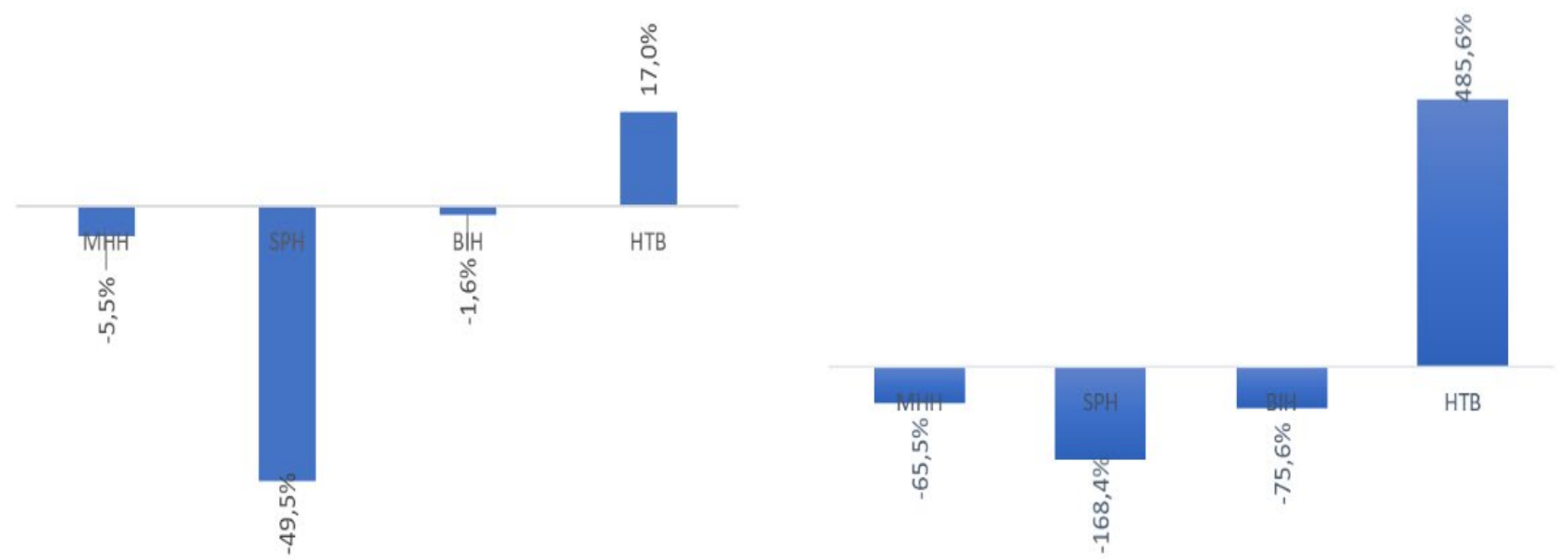

Gambar 1. Perbandingan pertumbuhan pendapatan dan laba bersih setelah pajak (HTB: Perusahaan terbuka yang bergerak di industri perhotelan)

Dari perspektif operator hotel, pembeda antara operator hotel tersebut dengan operator hotel lainnya dapat dilihat dari brand, desain, standar layanan, sistem reservasi, dan dukungan global logistik (Contraktor dan Kundu 1998). Tetapi jika perbedaan ini tidak dapat memberikan dampak dalam bentuk peningkatan kinerja keuangan untuk pemilik hotel, maka pemilik hotel akan segera menyadari bahwa investasi yang dikeluarkan untuk penggunaan operator hotel tidak sebanding dengan peningkatan nilai asset yang mereka miliki. Dengan kata lain, operator hotel harus meningkatkan efisiensi dalam operasional dengan meningkatkan penjualan dan atau mengurangi biaya (Yoo et al. 1998, Tsaur 2000, Ismani et al. 2011).

Hua et al. (2017) meneliti mengenai hubungan fee yang dibayarkan kepada operator dengan tingkat Revenue per Availability Room (RevPAR) yang dihasilkan. Penelitian menunjukkan bahwa penggunaan operator hotel menambah nilai hotel dan memiliki pengaruh kepada kinerja hotel (O’Neill dan Carlback 2011) dan bahwa kekuatan merek dan pengenalan merek dapat menghasilkan keuntungan positif bagi bisnis (Damonte et al. 1997). Imbalan jasa manajemen yang dibayarkan kepada AHH adalah sebesar $6 \%$ dari gross sales (belum termasuk PPN) dan evaluasi kinerja keuangan dapat dilakukan menggunakan rasio keuangan dan economic value added (Syahran 2016).

AHH sebagai cucu perusahaan dari BUMN yang memiliki jaringan di seluruh Indonesia memiliki kekuatan seperti prioritas penggunaan hotel oleh karyawan BUMN tersebut, merek nasional, dan program loyalitas pelanggan yang digunakan secara grup. Hal tersebut selaras dengan penelitian yang dilakukan Nikolskaya et al. (2017) dan Sheresheva et al. (2018) dimana operator hotel memberikan nilai tambah dari sumber daya bersama dan jaringan yang dimiliki untuk mengembangkan hotel yang dikelolanya.

Kewenangan AHH sebagai operator hotel diwakili oleh adanya General Manager (GM) di masing-masing hotel yang berstatus kepegawaian AHH. Penyampaian laporan kinerja dilakukan GM kepada AHH setiap sebulan sekali melalui rapat kinerja bulanan dan AHH mempertanggungjawabkan kinerja hotel yang dikelolanya sebelum Rapat Umum Pemegang Saham (RUPS) masing-masing hotel. Kewenangan $\mathrm{AHH}$ di hotel milik XYZ cukup besar dengan adanya pengalihan pengelolaan hotel kepada AHH meliputi aspek pemasaran, operasional, sumber daya manusia, pelaporan keuangan, dan pengajuan investasi. Namun, selama lima tahun terakhir terdapat beberapa indikator keuangan $\mathrm{MHH}, \mathrm{SPH}$, dan BIH yang tidak tercapai.

Selama periode pengelolaan hotel oleh AHH, ketiga hotel membayarkan dividen kepada XYZ selaku pemegang saham. Dividen tersebut mempengaruhi kinerja keuangan hotel terutama kepada kondisi kas setara kas, ekuitas, dan asset sehingga berdampak kepada penurunan rasio keuangan. Untuk itu, perlu diteliti pula apakah $\mathrm{AHH}$ memberikan dampak terhadap kinerja keuangan $\mathrm{MHH}$, SPH, dan $\mathrm{BIH}$ dengan melakukan simulasi tanpa pembayaran dividen. 
AHH sebagai operator hotel diberikan kewenangan dalam mengelola hotel sehingga diharapkan memberikan kinerja yang optimal. Kinerja $\mathrm{AHH}$ sebagai operator terlihat dari tingkat produktivitas dan efisiensi hotel yang digambarkan dari tingkat hunian kamar, pendapatan per jumlah kamar tersedia, dan laba operasi yang dihasilkan. Pentingnya peran operator hotel bagi pemilik hotel akan berdampak pada kinerja bisnis hotel. Penelitian ini menganalisis kinerja keuangan ketiga hotel milik XYZ dengan adanya penggunaan AHH sebagai operator hotel dan melihat apakah penggunaan AHH memberikan nilai tambah pada hotel XYZ sehingga diharapkan memberikan gambaran mengenai kinerja hotel XYZ selama periode penelitian.

\section{METODE PENELITIAN}

Penelitian menggunakan pendekatan kuantitatif dengan data sekunder dari laporan tahunan dan laporan keuangan audit hotel $\mathrm{MHH}, \mathrm{SPH}$, dan BIH periode tahun 2001 sampai dengan tahun 2018. Variabel yang digunakan dalam penelitian adalah sebagai berikut:

1. Pengukuran likuiditas menggunakan:
a. Current ratio $=$ Current asset $\div$ Current Liability
b. Net working capital to total assets $=$ Net working capital $\div$ Total asset
c. Quick ratio $=$ (Current asset - inventory) $\div$ Current liability

2. Pengukuran solvabilitas menggunakan:
a. Debt to equity ratio $=$ Total liability $\div$ Total equity
b. Debt to total asset ratio $=$ Total liability $\div$ Total asset

3. Pengukuran profitabilitas menggunakan:
a. Net profit margin $=$ Net income $\div$ Net sales
b. Return on equity = Net income $\div$ Shareholder's equity
c. NOP margin $=$ Net Operating Profit $\div$ Net sales

4. Pengukuran aktivitas menggunakan:
a. Receivable turnover $=$ Sales $\div$ Account Receivable
b. Total asset turnover $=$ Sales $\div$ Total asset
c. Inventory turnover $=$ Cost of sales $\div$ Inventory

5. Dividend Payout ratio $=$ Dividend $\div$ Net profit
6. Nilai tambah perusahaan digambarkan dengan Economic Value Added (EVA)

Data sekunder yang telah terkumpul akan dianalisis menggunakan rasio keuangan masing-masing perusahaan dan nilai tambah perusahaan (EVA). Analisis yang digunakan adalah analisis deskriptif, dimana setelah data diperoleh dan diolah, data dianalisis dan dibandingkan sehingga dapat bermanfaat bagi penelitian (Lind et al. 2011).

Kinerja keuangan yang telah dihitung baik kondisi aktual maupun simulasi dengan skenario tanpa pembayaran dividen selanjutnya dianalisis uji beda menggunakan uji t-independen dengan alpha 5\%. Uji t-independen merupakan bagian dari uji hipotesis komparatif atau uji perbandingan. Uji t-independen bertujuan untuk mengetahui apakah terdapat perbedaan rata-rata yang bermakna antara dua kelompok bebas yang berskala interval atau rasio. Syarat untuk melakukan pengujian dengan uji $\mathrm{t}$ independen adalah data penelitian harus berdistribusi normal. Untuk itu, perlu dilakukan uji normalitas terlebih dahulu. Setelah dilakukan uji normalitas, tahapan selanjutnya adalah uji homogenitas (spssindonesia.com, 2019).

\section{HASIL}

\section{MHH}

MHH merupakan hotel milik XYZ yang berlokasi di Sanur, Bali dan mulai beroperasi komersial pada tahun 1974. Pada tanggal 15 Juni 2017, MHH melakukan amandemen perjanjian jasa manajemen dengan $\mathrm{AHH}$ dimana ditetapkan imbalan jasa manajemen kepada AHH adalah sebesar $6 \%$ dari gross sales (belum termasuk PPN). Perjanjian jasa manajemen tersebut akan berakhir pada tanggal 31 Mei 2020 dengan ruang lingkup perjanjian jasa pengelolaan hotel meliputi pelaksanaan perijinan, pengelolaan sumber daya manusia, pelaporan keuangan, penentuan tarif harga, penunjukkan kontraktor hotel, pengelolaan persediaan, penyusunan program promosi, dan segala kegiatan yang berhubungan dengan kegiatan usaha hotel.

Berdasarkan kinerja operasional MHH di tahun 2001 hingga tahun 2009 atau pada periode sebelum dikelola oleh AHH, MHH mencatatkan tingkat hunian kamar yang menunjukkan penurunan di tahun 2003 hingga 2006 akibat penurunan jumlah tamu sebagai dampak dari 
Bom Bali. Dengan kondisi keamanan yang membaik, hingga tahun 2009 rata-rata pertumbuhan tingkat hunian kamar MHH sebesar $0.7 \%$ dan tarif kamar ratarata sebesar $4.2 \%$. Sesudah dikelola oleh AHH di tahun 2010, terjadi peningkatan rata-rata tarif kamar rata-rata sebesar $6.4 \%$, namun kondisi sebaliknya terjadi pada penurunan tingkat hunian kamar sebagaimana pada Tabel 2.

Tabel 2. CAGR kinerja operasional MHH

\begin{tabular}{lcc}
\hline & $\begin{array}{c}\text { CAGR sebelum } \\
\text { dikelola AHH }\end{array}$ & $\begin{array}{c}\text { CAGR sesudah } \\
\text { dikelola AHH }\end{array}$ \\
\hline $\begin{array}{l}\text { Tingkat hunian } \\
\text { kamar }\end{array}$ & $0,7 \%$ & $-0,1 \%$ \\
$\begin{array}{l}\text { Tarif kamar rata- } \\
\text { rata }\end{array}$ & $4,2 \%$ & $6,4 \%$ \\
\hline
\end{tabular}

\section{Tren Pendapatan dan Biaya MHH}

Selama periode tahun 2001 hingga 2006, pendapatan MHH menunjukkan tren yang menurun dikarenakan Peristiwa Bom Bali sehingga berdampak kepada penurunan jumlah wisatawan ke Bali. Seiring dengan membaiknya situasi keamanan di Indonesia yang semakin kondusif, tingkat kunjungan wisatawan ke Indonesia kembali meningkat dan berdampak kepada peningkatan pendapatan $\mathrm{MHH}$ pada periode setelah tahun 2006 hingga 2018.

Setelah dikelola oleh AHH mulai bulan Oktober 2010, di tahun 2011 MHH mencatatkan peningkatan pendapatan sebesar $21.0 \%$ dibandingkan tahun 2010 dan peningkatan laba setelah pajak sebesar $87.0 \%$. Peningkatan pendapatan terutama berasal dari pendapatan kamar, makanan dan minuman dengan adanya peningkatan jumlah tamu.

Dilihat dari sisi biaya, seiring dengan peningkatan pendapatan, MHH menunjukkan tren peningkatan biaya baik dari sisi biaya pokok, biaya operasi, dan biaya operasi lain-lain. Inflasi harga bahan baku, kenaikan biaya SDM, kenaikan tarif dasar listrik, dan kenaikan biaya management fee menjadi penyebab dari kenaikan biaya MHH. Gross profit margin dari MHH sesudah dikelola AHH berada pada kisaran 53$61 \%$. Rata-rata nilai Gross profit margin untuk hotel berbintang lima adalah sebesar $58,1 \%$. Nilai Gross profit margin memperlihatkan tingkat efisiensi $\mathrm{AHH}$ sebagai operator hotel.
Management fee yang merupakan imbalan atas jasa pengelolaan AHH masuk ke dalam komponen biaya operasi lain-lain. Pada Tabel 3 dapat dilihat bahwa pertumbuhan CAGR pendapatan sesudah dikelola AHH sebesar 7.4\%, lebih kecil dibandingkan dengan pertumbuhan CAGR (Compound Annual Growth Rate) biaya operasi lain-lain sebesar $18.6 \%$. Hal tersebut menunjukkan bahwa AHH belum memberikan dampak terhadap peningkatan pendapatan bagi $\mathrm{MHH}$ dibandingkan dengan peningkatan biaya yang harus dikeluarkan oleh MHH untuk management fee kepada AHH. Selain itu pertumbuhan pendapatan $\mathrm{MHH}$ sesudah dikelola AHH juga lebih rendah dibandingkan dengan pertumbuhan PDRB Provinsi Bali yang sebesar $14.9 \%$

Tabel 3. CAGR pendapatan dan biaya MHH

\begin{tabular}{lcc}
\hline & $\begin{array}{c}\text { CAGR sebelum } \\
\text { dikelola AHH }\end{array}$ & $\begin{array}{c}\text { CAGR sesudah } \\
\text { dikelola AHH }\end{array}$ \\
\hline Sales & $5,5 \%$ & $7,4 \%$ \\
Cost of Revenue & $5,1 \%$ & $9,2 \%$ \\
Operating & $3,1 \%$ & $7,2 \%$ \\
Expenses & & \\
Other Operating & $7,7 \%$ & $18,6 \%$ \\
Expenses & & \\
\hline
\end{tabular}

\section{Dividend Payout Ratio (DPR)}

Terlihat pada Tabel 4 bahwa sebelum dikelola $\mathrm{AHH}$, MHH membayarkan dividen hanya pada tahun 2009 dengan dividend payout ratio sebesar $47 \%$ dari laba bersih. XYZ selaku pemegang saham mulai menarik dividen dari MHH seiring dengan membaiknya kinerja profitabilitas MHH. Dividend payout ratio tertinggi dilakukan MHH pada tahun 2010 dengan nilai dividend payout ratio sebesar $150 \%$ dari laba bersih.

Tabel 4. Dividend Payout Ratio (DPR) MHH

\begin{tabular}{cccc}
\hline Tahun & $\begin{array}{c}\text { DPR sebelum } \\
\text { dikelola AHH }\end{array}$ & Tahun & $\begin{array}{c}\text { DPR sesudah } \\
\text { dikelola AHH }\end{array}$ \\
\hline 2001 & $0 \%$ & 2010 & $150 \%$ \\
2002 & $0 \%$ & 2011 & $38 \%$ \\
2003 & $0 \%$ & 2012 & $75 \%$ \\
2004 & $0 \%$ & 2013 & $53 \%$ \\
2005 & $0 \%$ & 2014 & $108 \%$ \\
2006 & $0 \%$ & 2015 & $66 \%$ \\
2007 & $0 \%$ & 2016 & $54 \%$ \\
2008 & $0 \%$ & 2017 & $81 \%$ \\
2009 & $47 \%$ & 2018 & $35 \%$ \\
\hline
\end{tabular}




\section{Hasil Uji T Independen}

Uji t independen dilakukan dengan durasi tahun 20062018, yaitu empat tahun sebelum dan sembilan tahun setelah MHH dikelola oleh AHH. Durasi empat tahun sebelum dikelola AHH diambil dengan mengeluarkan periode 2001 hingga 2005 dimana MHH terpapar dampak Bom Bali I dan II untuk memberikan perbandingan yang seimbang dengan kondisi sesudah dikelola $\mathrm{AHH}$.

Dari hasil uji perbedaan untuk profitabilitas $\mathrm{MHH}$, diketahui bahwa nilai NOP, NPM, ROE tidak terdapat perbedaan yang nyata antara sebelum dan sesudah dikelola AHH, baik untuk kondisi aktual maupun untuk simulasi skenario tanpa pembayaran dividen.

Hasil uji t untuk likuiditas MHH adalah terdapat perbedaan yang nyata antara sebelum dan sesudah dikelola AHH untuk quick ratio dan current ratio. Terjadi peningkatan likuiditas MHH sesudah dikelola AHH akibat adanya peningkatan aset lancar dari kas setara kas dan piutang usaha.

Uji statistik terhadap solvabilitas MHH memperlihatkan bahwa tidak terdapat perbedaan yang signifikan antara sebelum dan sesudah dikelola AHH. Tingkat hutang MHH masih dapat dikelola oleh perusahaan sehingga MHH tidak terpapar risiko gagal bayar.

Tabel 5. Hasil Uji T Independen MHH

\begin{tabular}{lcc}
\hline Variabel & $\begin{array}{c}\text { Dengan } \\
\text { Dividen }^{\mathrm{a}}\end{array}$ & $\begin{array}{c}\text { Simulasi Tanpa } \\
\text { Dividen }^{\mathrm{a}}\end{array}$ \\
\hline NOP & - & - \\
NPM & - & - \\
ROE & - & - \\
Quick Ratio & $\mathrm{X}$ & $\mathrm{X}$ \\
Current Ratio & $\mathrm{X}$ & $\mathrm{X}$ \\
Net Working Capital to & - & - \\
Total Asset & & \\
Debt to Equity Ratio & - & - \\
Debt to total Asset & - & - \\
Ratio & & \\
Account Receivable & - & - \\
turnover & & \\
Inventory turnover & $\mathrm{X}$ & $\mathrm{X}$ \\
Total Asset turnover & $\mathrm{X}$ & $\mathrm{X}$ \\
EVA & - & - \\
Ketrangan: X(terdapat perbern);
\end{tabular}

Keterangan: X (terdapat perbedaan); - (tidak terdapat

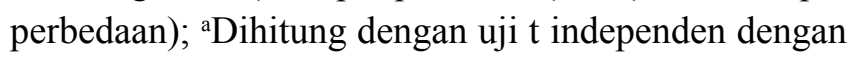
alpha $5 \%$
Pengelolaan $\mathrm{MHH}$ oleh AHH pada rasio aktivitas memberikan perbedaan pada inventory turnover dan total asset turnover. AHH sebagai operator hotel MHH mengelola perputaran persediaan yang lebih cepat sehingga persediaan yang ada di MHH dapat digunakan dengan lebih efektif dan efisien. Namun jika dilihat dari perputaran aset, pengelolaan $\mathrm{AHH}$ tidak memberikan perputaran aset yang lebih cepat dikarenakan pertumbuhan pendapatan yang dihasilkan MHH tidak sebesar pertumbuhan aset.

Nilai EVA MHH pada periode pengelolaan AHH menunjukkan tren yang menurun di tahun 2014 hingga tahun 2018. Tidak adanya perbedaan yang signifikan pada EVA MHH antara sebelum dan sesudah dikelola AHH menunjukkan bahwa AHH tidak memberikan nilai tambah bagi XYZ dalam pengelolaan hotelnya.

\section{SPH}

SPH merupakan hotel milik XYZ yang berlokasi di Lombok, Nusa Tenggara Barat dan mulai beroperasi komersial pada tahun 1974. Pada tanggal 15 Juni 2017, SPH melakukan amandemen perjanjian jasa manajemen dengan AHH dimana ditetapkan imbalan jasa manajemen kepada AHH adalah sebesar 6\% dari gross sales (belum termasuk PPN). Perjanjian jasa manajemen tersebut akan berakhir pada tanggal 31 Mei 2020 dengan ruang lingkup jasa pengelolaan hotel sama seperti MHH.

Kinerja operasional SPH menunjukkan adanya peningkatan tingkat hunian kamar sesudah dikelola oleh AHH. Tingkat hunian kamar tertinggi tercatat terjadi pada tahun 2017 dengan jumlah kamar dihuni sebanyak 46.878 kamar dan tarif kamar rata-rata sebesar Rp694.707.

\section{Tren Pendapatan dan Biaya SPH}

Selama tahun 2001-2006, pendapatan usaha SPH menunjukkan tren yang menurun dikarenakan kondisi keamanan dan politik di Indonesia akibat kerusuhan di Lombok dan aksi terorisme di Bali yang berdampak kepada menurunnya jumlah tamu khususnya wisatawan mancanegara ke daerah Lombok. Pada tahun 2007 kondisi keamanan Indonesia mulai pulih sehingga wisatawan kembali datang ke Indonesia.

Dilihat dari sisi biaya, seiring dengan peningkatan pendapatan, SPH menunjukkan tren peningkatan biaya 
baik dari sisi biaya pokok, biaya operasi, dan biaya operasi lain-lain. Struktur biaya usaha SPH didominasi oleh biaya makanan dan minuman yang mencapai $20,7 \%$ dari total pendapatan. Sementara pendapatan dari makanan dan minuman hanya memberikan kontribusi sebesar 32,7\% dari total pendapatan SPH. Gross profit margin dari SPH sesudah dikelola AHH berada pada kisaran 54\% - 62\%. Rata-rata nilai Gross profit margin untuk hotel berbintang empat adalah sebesar $56,4 \%$.

Tren peningkatan biaya paling tinggi adalah biaya operasi yang didominasi oleh kenaikan biaya SDM dan biaya operasi lain-lain dalam hal ini management fee yang dibayarkan SPH ke AHH. Pada Tabel 6 dapat dilihat bahwa pertumbuhan CAGR pendapatan sesudah dikelola AHH sebesar 10,2\%, lebih kecil dibandingkan dengan pertumbuhan CAGR biaya operasi lain-lain sebesar $13,3 \%$.

Tabel 6. CAGR pendapatan dan biaya SPH

\begin{tabular}{lcc}
\hline & $\begin{array}{c}\text { CAGR sebelum } \\
\text { dikelola AHH }\end{array}$ & $\begin{array}{c}\text { CAGR sesudah } \\
\text { dikelola AHH }\end{array}$ \\
\hline Sales & $-1,8 \%$ & $10,2 \%$ \\
Cost of Revenue & $2,5 \%$ & $8,4 \%$ \\
$\begin{array}{l}\text { Operating } \\
\begin{array}{l}\text { Expenses } \\
\text { Other Operating }\end{array}\end{array}$ & $0,5 \%$ & $11,6 \%$ \\
Expenses & $-16,4 \%$ & $13,3 \%$ \\
\hline
\end{tabular}

Dari Tabel 6 dapat dilihat bahwa AHH belum memberikan dampak terhadap peningkatan pendapatan bagi SPH dibandingkan dengan peningkatan biaya yang harus dikeluarkan oleh SPH untuk management fee kepada AHH. Selain itu pertumbuhan pendapatan SPH sesudah dikelola AHH juga lebih rendah dibandingkan dengan pertumbuhan PDRB Provinsi Nusa Tenggara Barat yang sebesar $13,2 \%$.

\section{Dividend Payout Ratio (DPR)}

SPH membayarkan dividen kepada XYZ mulai tahun 2006. Pembayaran dividen terbesar dilakukan oleh SPH pada tahun 2012 dengan nilai dividend payout ratio sebesar $738 \%$. Pembayaran dividen tersebut mempengaruhi kinerja likuiditas SPH dimana pada tahun 2012 merupakan tahun dimana nilai Current Ratio dan Quick Ratio terendah selama periode penelitian, meskipun masih berada di atas $100 \%$.

\section{Tabel 7. Dividend Payout Ratio (DPR) SPH}

\begin{tabular}{cccc}
\hline Tahun & $\begin{array}{c}\text { DPR sebelum } \\
\text { dikelola AHH }\end{array}$ & Tahun & $\begin{array}{c}\text { DPR sesudah } \\
\text { dikelola AHH }\end{array}$ \\
\hline 2001 & $0 \%$ & 2010 & $337 \%$ \\
2002 & $0 \%$ & 2011 & $52 \%$ \\
2003 & $0 \%$ & 2012 & $738 \%$ \\
2004 & $0 \%$ & 2013 & $0 \%$ \\
2005 & $0 \%$ & 2014 & $0 \%$ \\
2006 & $498 \%$ & 2015 & $17 \%$ \\
2007 & $270 \%$ & 2016 & $0 \%$ \\
2008 & $44 \%$ & 2017 & $95 \%$ \\
2009 & $283 \%$ & 2018 & $83 \%$ \\
\hline
\end{tabular}

\section{Hasil Uji T Independen}

Uji t independen dilakukan dengan durasi tahun 20062018, yaitu empat tahun sebelum dan sembilan tahun setelah SPH dikelola oleh AHH. Durasi empat tahun sebelum dikelola $\mathrm{AHH}$ diambil dengan mengeluarkan periode 2001 hingga 2005 dimana SPH terpapar dampak Bom Bali I dan II untuk memberikan perbandingan yang seimbang dengan kondisi sesudah dikelola $\mathrm{AHH}$.

Rasio profitabilitas SPH memperlihatkan bahwa tidak terdapat perbedaan yang nyata antara sebelum dan sesudah dikelola AHH. Manajemen AHH gagal untuk meningkatkan profitabilitas perusahaan dengan terlihat pada stagnannya nilai profitabilitas SPH antara sebelum dan sesudah dikelola $\mathrm{AHH}$.

Hasil uji $\mathrm{t}$ untuk likuiditas SPH adalah terdapat perbedaan yang nyata antara sebelum dan sesudah dikelola AHH. Terjadi penurunan kas setara kas akibat adanya pembayaran dividen dan kenaikan kewajiban lancar akibat peningkatan tingkat hunian kamar. Kemampuan membayar kewajiban jangka pendek SPH masih tinggi dikarenakan aset lancar SPH masih likuid dengan didominasi oleh kas setara kas. Dengan dilakukannya simulasi tanpa pembayaran dividen, hasil uji statistik menunjukkan hasil yang sama dengan kondisi aktual dikarenakan nilai dividen secara nominal tidak sebanding dengan besarnya nilai aset $\mathrm{SPH}$. 
Tabel 8. Hasil Uji T Independen SPH

\begin{tabular}{lcc}
\hline Variabel & $\begin{array}{c}\text { Dengan } \\
\text { Dividen }^{\mathrm{a}}\end{array}$ & $\begin{array}{c}\text { Simulasi Tanpa } \\
\text { Dividen }^{\mathrm{a}}\end{array}$ \\
\hline NOP & - & - \\
NPM & - & - \\
ROE & - & - \\
Quick Ratio & $\mathrm{X}$ & $\mathrm{X}$ \\
Current Ratio & $\mathrm{X}$ & $\mathrm{X}$ \\
Net Working Capital to & - & - \\
Total Asset & & - \\
Debt to Equity Ratio & - & - \\
Debt to total Asset & - & - \\
Ratio & & - \\
Account Receivable & - & - \\
turnover & & - \\
Inventory turnover & - & \\
Total Asset turnover & - & - \\
EVA & - & \\
\hline Keterangan: X (terdapat perbedaan); &
\end{tabular}

Keterangan: X (terdapat perbedaan); - (tidak terdapat perbedaan); ${ }^{a}$ Dihitung dengan uji $t$ independen dengan alpha $5 \%$

Selama periode penelitian, SPH tidak memiliki pinjaman kepada bank untuk membiayai pengelolaan perusahaan sehingga SPH masih memiliki ruang untuk mengoptimalkan asetnya melalui utang yang diharapkan dapat memberikan imbal balik yang lebih tinggi.

Uji t terhadap activity SPH menunjukkan bahwa tidak terdapat perbedaan yang signifikan antara sebelum dan sesudah dikelola oleh AHH. AHH tidak memberikan pengelolaan yang lebih efisien pada SPH dikarenakan baik untuk rasio account receivable turnover, inventory turnover, dan total asset turnover tidak berbeda secara signifikan.

Pengelolaan SPH oleh AHH tidak memberikan perbedaan kepada nilai tambah yang diterima oleh XYZ selaku pemilik hotel. Nilai EVA SPH menunjukkan tidak berbeda signifikan antara sebelum dan sesudah dikelola oleh AHH dengan nilai EVA positif. Nilai EVA SPH yang positif artinya terdapat penambahan nilai perusahaan secara ekonomi dan memiliki kinerja keuangan yang baik. Terjadi peningkatan EBIT karena semakin meningkatnya pendapatan SPH dan struktur modal sendiri yang mendominasi permodalan SPH memperlihatkan bahwa SPH memiliki risiko yang rendah.

\section{BIH}

BIH merupakan hotel milik XYZ dan MRT yang berlokasi di Bandung, Jawa Barat dan mulai beroperasi komersial pada tahun 1981. Berbeda dengan MHH dan SPH yang 99,9\% dimiliki oleh XYZ, BIH merupakan perusahaan patungan XYZ dan MRT sejak tahun 1981. BIH memiliki hak pengelolaan atas properti di Bandung dalam jangka waktu 30 tahun sejak dioperasikannya properti pada tahun 1990 dan akan berakhir pada tahun 2020. Atas hak pengelolaan properti tersebut, BIH dikenakan management fee sebesar $4 \%$ dari pendapatan ditambah dengan royalty sebesar Rp12,5 juta yang dibayarkan kepada pemerintah.

XYZ mengalihkan hak pengelolaan BIH kepada $\mathrm{AHH}$ mulai tahun 2010 dengan management fee sebesar 2\% dari pendapatan. Dengan kondisi keuangan BIH yang merugi, XYZ dan MRT selaku pemegang saham BIH menyepakati untuk tidak membayarkan management fee kepada AHH efektif tahun 2015. Selama periode penelitian, BIH mengalami penurunan rata-rata tingkat hunian kamar, baik sebelum maupun sesudah dikelola oleh AHH. Tarif kamar rata-rata sesudah dikelola $\mathrm{AHH}$ pun hanya mengalami kenaikan sebesar $1,1 \%$.

\section{Tren Pendapatan dan Biaya BIH}

Pendapatan BIH di tahun 2001 tercatat sebesar Rp20,5 miliar dan menunjukkan peningkatan CAGR sebesar $7,1 \%$ hingga tahun 2009 . Seiring dengan meningkatnya persaingan bisnis hotel di Bandung dimana terjadi peningkatan penggunaan situs website hotel serta online travel agent (Tirtayasa dan Paturusi, 2016), kinerja pendapatan BIH menunjukkan stagnansi pada tahun 2010 hingga tahun 2018 dengan pertumbuhan CAGR pendapatan sebesar $0,1 \%$.

Dengan adanya penangguhan pembayaran management fee BIH kepada AHH mulai tahun 2015, biaya operasi lain-lain BIH menurun sebesar 7,3\%. Namun, hal tersebut tidak cukup membantu meningkatkan laba BIH dikarenakan pendapatan BIH yang menurun pada tahun 2015. Struktur biaya usaha BIH didominasi oleh biaya makanan dan minuman yang mencapai $28,3 \%$ dari total pendapatan. Sementara pendapatan dari makanan dan minuman hanya memberikan kontribusi sebesar 35,7\% dari total pendapatan. Gross profit margin dari MHH sesudah dikelola AHH berada pada kisaran 53\%- 60\%. Rata-rata nilai Gross profit margin untuk hotel berbintang lima adalah sebesar $58,1 \%$. 
Kenaikan biaya BIH terjadi cukup signifikan pada beban operasi terutama SDM dikarenakan hampir $80.0 \%$ dari total karyawan memasuki masa pensiun pada tahun 2015 hingga 2018. Hal tersebut cukup membebani kinerja keuangan BIH. Kondisi penjualan $\mathrm{BIH}$ yang stagnan juga turut memperburuk kinerja keuangan $\mathrm{BIH}$.

Tabel 9. CAGR pendapatan dan biaya BIH

\begin{tabular}{lcc}
\hline & $\begin{array}{c}\text { CAGR sebelum } \\
\text { dikelola AHH }\end{array}$ & $\begin{array}{c}\text { CAGR sesudah } \\
\text { dikelola AHH }\end{array}$ \\
\hline Sales & $7,1 \%$ & $0,1 \%$ \\
Cost of Revenue & $5,6 \%$ & $4,4 \%$ \\
$\begin{array}{l}\text { Operating } \\
\text { Expenses }\end{array}$ & $5,8 \%$ & $5,6 \%$ \\
$\begin{array}{l}\text { Other Operating } \\
\text { Expenses }\end{array}$ & $4,0 \%$ & $-3,3 \%$ \\
\hline
\end{tabular}

Pada Tabel 9 dapat dilihat bahwa pertumbuhan CAGR pendapatan sesudah dikelola AHH sebesar 0,1\% lebih kecil dibandingkan dengan pertumbuhan CAGR pendapatan sebelum dikelola AHH sebesar 7,1\%. Hal tersebut menunjukkan bahwa AHH belum memberikan dampak terhadap peningkatan pendapatan bagi BIH. Selain itu pertumbuhan pendapatan BIH sesudah dikelola AHH juga jauh lebih rendah dibandingkan dengan pertumbuhan PDRB Provinsi Jawa Barat yang sebesar 7,3\%.

\section{Dividend Payout Ratio}

Pembayaran dividen oleh BIH kepada XYZ dan MRT hanya dilakukan dua kali selama periode penelitian, yaitu pada tahun 2011 dan 2012. Kondisi likuiditas BIH yang semakin menurun tidak disebabkan oleh adanya pembayaran dividen, namun lebih dikarenakan tren pendapatan yang menurun mengakibatkan kas setara kas BIH juga ikut terdampak hal tersebut. Posisi ekuitas BIH juga menunjukkan tren yang menurun dikarenakan $\mathrm{BIH}$ mengalami kerugian selama empat tahun terakhir.

\section{Hasil Uji T Independen}

Uji t independen dilakukan dengan durasi tahun 20062018, yaitu empat tahun sebelum dan sembilan tahun setelah SPH dikelola oleh AHH. Durasi empat tahun sebelum dikelola AHH diambil dengan mengeluarkan periode 2001 hingga 2005 dimana BIH terpapar dampak restrukturisasi utang untuk memberikan perbandingan yang seimbang dengan kondisi sesudah dikelola $\mathrm{AHH}$.

Untuk profitabilitas BIH, AHH gagal untuk meningkatkan profitabilitas BIH dikarenakan semakin besarnya kerugian dan adanya defisit laba ditahan atau negative retained earning.

Dari sisi likuiditas, terjadi penurunan persediaan dan piutang berelasi BIH sesudah dikelola AHH. Peningkatan kewajiban lancar BIH dari pendapatan diterima dimuka dan pinjaman jatuh tempo dalam waktu satu tahun juga menjadi penyebab menurunnya likuiditas BIH.

Sesudah dikelola $\mathrm{AHH}$, nilai current ratio $\mathrm{BIH}$ mengalami penurunan hingga hanya mencapai $51.0 \%$ di tahun 2018. Ketatnya aset lancar dan meningkatnya kewajiban lancar mengakibatkan modal kerja BIH mengalami penurunan dengan dikelola $\mathrm{AHH}$. Pengelolaan BIH oleh AHH secara nyata memberikan perbedaan pada kinerja likuiditas BIH dari rasio quick ratio, current ratio, dan Net Working Capital to Total Asset dimana likuiditas BIH sesudah dikelola $\mathrm{AHH}$ mengalami penurunan.

Tabel 10. Hasil Uji T Independen BIH

\begin{tabular}{lcc}
\hline Variabel & $\begin{array}{c}\text { Dengan } \\
\text { Dividen }^{\mathrm{a}}\end{array}$ & $\begin{array}{c}\text { Simulasi Tanpa } \\
\text { Dividen }^{\mathrm{a}}\end{array}$ \\
\hline NOP & $\mathrm{X}$ & $\mathrm{X}$ \\
NPM & $\mathrm{X}$ & $\mathrm{X}$ \\
ROE & - & - \\
Quick Ratio & $\mathrm{X}$ & $\mathrm{X}$ \\
Current Ratio & $\mathrm{X}$ & $\mathrm{X}$ \\
Net Working Capital to & $\mathrm{X}$ & $\mathrm{X}$ \\
Total Asset & & \\
Debt to Equity Ratio & - & - \\
Debt to total Asset & - & - \\
Ratio & & \\
Account Receivable & - & - \\
turnover & & $\mathrm{X}$ \\
Inventory turnover & $\mathrm{X}$ & $\mathrm{X}$ \\
Total Asset turnover & $\mathrm{X}$ & $\mathrm{X}$ \\
EVA & $\mathrm{X}$ & \\
\hline
\end{tabular}

Keterangan: X (terdapat perbedaan); - (tidak terdapat perbedaan); ${ }^{a}$ Dihitung dengan uji $t$ independen dengan alpha 5\% 
Struktur permodalan BIH sesudah dikelola AHH menunjukkan kewajiban BIH yang semakin meningkat dengan nilai tertinggi di tahun 2016. Bahkan di tahun 2018 BIH memiliki nilai kewajiban enam kali lipat dibandingkan ekuitas pada tahun 2018. Kondisi tersebut berpotensi mengakibatkan BIH tidak mampu memenuhi kewajiban utangnya dari modal sendiri.

Hasil uji statistik untuk rasio aktivitas BIH menunjukkan bahwa pengelolaan AHH di BIH tidak memberikan perbedaan untuk perputaran piutang, peningkatan efektivitas persediaan terlihat dengan adanya tingkat perputaran persediaan yang lebih cepat, dan untuk perputaran aset tidak berdampak signifikan terhadap peningkatan pendapatan. Perputaran aset BIH sesudah dikelola AHH lebih rendah dibandingkan sebelum dikelola AHH. Hal tersebut dikarenakan pendapatan BIH sesudah dikelola AHH stagnan dengan pertumbuhan CAGR hanya sebesar $0,1 \%$. Pertumbuhan pendapatan tersebut tidak sebanding dengan pertumbuhan aset BIH sehingga efektivitas pengelolaan aset $\mathrm{BIH}$ tidak terlihat pada periode pengelolaan $\mathrm{AHH}$.

EVA sesudah dikelola AHH menunjukkan nilai yang negatif. Jika nilai EVA $<0$ maka tidak terjadi proses penciptaan nilai oleh perusahaan (O'Bryne, 1996). EVA negatif diartikan sebagai penurunan kemakmuran bagi para pemegang saham (Mustoffa, 2014). Pada tahun 2012, BIH mendapatkan pinjaman bank yang digunakan untuk merenovasi kamar dan fasilitas hotel, namun investasi tersebut tidak memberikan leverage bagi peningkatan pendapatan $\mathrm{BIH}$ di tahun-tahun selanjutnya dimana pendapatannya cenderung stagnan sebagaimana pada Tabel 9.

\section{Implikasi Manajerial}

Dalam upaya meningkatkan kinerja keuangan ketiga hotel dengan adanya pengelolaan oleh AHH maka perlu dirumuskan program pendukung diantara: 1) Penghematan kegiatan operasional harus dilakukan agar terhindar dari kerugian yang berkelanjutan. Selain itu beban sumber daya manusia juga membebani perusahaan dikarenakan tingginya biaya kewajiban jangka Panjang. XYZ perlu menyesuaikan jumlah sumber daya manusia yang digunakan untuk operasional hotel sehingga produktivitas karyawan sebanding dengan biaya yang dikeluarkan; 2) XYZ sebaiknya meningkatkan pembiayaan melalui utang di MHH dan SPH dikarenakan berbiaya relatif lebih rendah dibandingkan pembiayaan ekuitas sehingga dapat meningkatkan laba atas ekuitas; 3) Khusus untuk BIH, XYZ sebagai pemegang saham perlu melakukan pembenahan porsi utang dan peningkatan likuiditas bagi BIH untuk dapat memperbaiki kinerja keuangan; 4) Dampak pengelolaan hotel-hotel milik XYZ oleh AHH pada kinerja keuangan dan nilai tambah perusahaan tidak dirasakan pada beberapa rasio keuangan. Bahkan pada ketiga hotel milik XYZ tersebut pengelolaan $\mathrm{AHH}$ tidak memberikan nilai tambah dikarenakan nilai EVA tidak berbeda signifikan antara sebelum dan sesudah dikelola $\mathrm{AHH}$.

\section{KESIMPULAN DAN SARAN}

\section{Kesimpulan}

Kinerja keuangan hotel MHH dan SPH dari rasio profitabilitas, likuiditas, solvabilitas, dan aktivitas cukup baik meskipun pada awal periode penelitian hingga tahun 2006 terdampak Bom Bali I dan II di Bali dan Lombok dan di tahun 2014 hingga 2017 terjadi kenaikan kewajiban jangka panjang akibat peningkatan kewajiban imbalan paska kerja. Kinerja keuangan hotel BIH menunjukkan tren kinerja keuangan dari rasio profitabilitas, likuiditas, dan solvabilitas yang buruk, dimana selama enam tahun terakhir mencatatkan kerugian dan EVA yang negatif. Hotel MHH dan SPH memiliki peluang untuk meningkatkan leverage melalui pembiayaan utang. Hasil uji statistik menggunakan uji $\mathrm{t}$ independen memperlihatkan bahwa AHH sebagai operator hotel gagal untuk meningkatkan kinerja keuangan, dimana tidak berbeda signifikan nilai rataratanya antara sebelum dan sesudah dikelola $\mathrm{AHH}$.

\section{Saran}

XYZ sebagai pemilik hotel MHH, SPH, dan BIH perlu meninjau ulang penggunaan AHH sebagai operator. Jika AHH masih digunakan sebagai operator hotel milik XYZ, maka XYZ sebaiknya menerapkan kontrol yang lebih ketat atas kinerja operator yang terlihat pada pencapaian kinerja operasional dan keuangan hotelnya. Jika XYZ memutuskan untuk mengganti operator hotel miliknya, maka XYZ sebaiknya perlu mempertimbangkan merek, jaringan, dan portofolio kinerja operator di hotel lain yang dikelola sebelumnya. 


\section{DAFTAR PUSTAKA}

Belk R. 2014. You are what you can access: Sharing and collaborative consumption online. Journal of Business Research 67(8):1595-1600.

Contractor FJ., Kundu SK. 1998. Franchising versus company-run operations: modal choice in the global hotel sector. Journal of International Marketing 6(2):28-53.

Damonte LT, Rompf PD, Domke DJ, Bahl R. 1997. Brand affiliation and property size effects on measures of performance in lodging properties. Hospitality Research Journal 20(3):1-16.

Eckhard GM, Bardhi F. 2015. The sharing economy isn't about sharing at all. Harvard Business Review Online. USA: Harvard Business School.

Hua N, O'Neill JW, Nusair K, Singh D. 2017. Does paying higher franchise fees command higher RevPAR? International Journal of Contemporary Hospitality Management 29(11):2941-2961.

Ismani, Setiawan N, Istiningrum AA. 2011. Analisis profitabilitas untuk mengukur kinerja keuangan manajemen hotel. Jurnal Pendidikan Akuntansi Indonesia 9(2): 72-78.

Juliana I, Pramono N. 2003. Telaah kontrak manajemen hotel jaringan internasional antara pihak pemilik dan pihak pengelola hotel menurut peraturan kepariwisataan di Bali [tesis]. Yogyakarta: Universitas Gadjah Mada.

Lind DA, Marchal WG, Wathen SA. 2011.TeknikTeknik Statistika Dalam Bisnis dan Ekonomi Menggunakan Kelompok Data Global. Jakarta: Penerbit Salemba Empat.

Mustoffa AF. 2014. Pengukuran kinerja keuangan dengan pendekatan Economic Value Added (EVA) dan Market Value Added (MVA). Jurnal Akuntansi dan Pajak. 13(2): 61-69.

Nikolskaya EY, Pasko OV, Volkova IA, Dekhtyar GM, Lebedeva OY. 2017. Boosting the competitiveness of hotel business operators in current conditions. Journal of Enivornmental Management and Tourism. 8(24):1629-1634.
O’Bryne SF, Stern JM, Stewart GB. 1996. EVA and market value. Journal of Applied Corporate Finance 9 (1): 116-125.

O'Neill JW, Carlback M. 2011. Do brands matter? A comparison of branded and independent hotels' performance during a full economic cycle. International Journal of Hospitality Management. 30(3):515-521.

Salvioni DM, 2016. Hotel chains and the sharing economy in global tourism. Symphony Emerging Issues in Management 1(1):31-44.

Sheresheva MY, Oborin MS, Polyanskaya EE. 2018. International hotel chains in Russia the prospects and challenges of movement from megacities to smaller cities in Russian regions. Worldwide Hospitality and Tourism Themes 10(4):421-435.

Susanto AB. 2013. Manajemen Strategik Komprehensif untuk Mahasiswa dan Praktisi. Jakarta: Erlangga.

Syahran R, Dedi BH, Dadang S. 2016. The evaluation on the financial performance of paper and pulp companies in Indonesia. Indonesian Journal of Business and Entrepreneurship 2(3):187-196.

Tirtayasa PP, Paturusi SA, 2016. Penggunaan situs web hotel dan online travel agent sebagai media promosi dan penjualan. Jurnal Master Pariwisata 3(1):60-71

Tsaur SH. 2000. The operating efficiency of international tourist hotels in Taiwan, Asia Pacific. Journal of Tourism Research 6(1):29-37.

Wiastuti RD, Susilowardhani EM. 2016. Virtual hotel operator, Is it disruption for hotel industry? Hospitality dan Pariwisata. 2(2):201-215.

Yoo B, Donthu N, Pilling PK. 1998. Channel efficiency: franchise vs non-franchise systems. Journal of Marketing Channels 6(3):1-15.

[WTTC] World Travel and Tourism Council. 2019. Travel and tourism economic impact 2019. https:// www.wttc.org/-/media/files/reports/economicimpact-research/regions-2019/world2019.pdf. [2019 September 07].

[XYZ] XYZ. 2018. Laporan Keuangan Audited Tahun 2018. Jakarta: XYZ. 